\title{
Assessing Technology-based Projects for Promotion and/or Tenure in ARL Academic Libraries
}

\section{Karen G. Lawson and Nancy L. Pelzer}

\begin{abstract}
Little is known about how technology-based projects (computer software, articles in electronic journals, Internet-based materials, videotapes and audiotapes) are reviewed for promotion and/or tenure purposes in academic libraries. Reviewers might evaluate projects with traditional criteria or attempt to revise criteria to accommodate computer-related work. To address this issue in more detail, the authors conducted a study to assess how technology-based projects are evaluated in the promotion and/or tenure process for academic librarians in Association of Research Libraries. Survey results show that, while projects, particularly World Wide Web-based materials, are being evaluated in some ARL academic libraries, little has been developed as a core set of measures or assessments for promotion and/or tenure decisions.
\end{abstract}

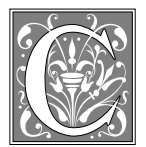

hanges in methods of publication and in the nature of research and its resulting products are raising difficult questions in the arena of the scholarly reward system. Several years ago, as administrators began to talk positively about technology and its benefits to the University community, efforts such as developing computer programs, writing reviews of software, and publishing in electronic journals were perceived by some in the academic world as coming into their own as legitimate forms of scholarship. ${ }^{1}$ By 1997, the winds on campuses appeared to have shifted and the earlier enthusiasm of scholars was being tempered by skeptical departments and committees reviewing candidates for promotion and/or tenure. ${ }^{2}$ The Modern Language Association's Guidelines for Evalu- ating Computer-related Work in the Modern Languages specifies "recognition of contributions by faculty members" as one of the guidelines for support of computer technology and recommends that "colleges and universities should develop a written policy concerning the evaluation of electronic publications in the tenure and promotion process so that faculty members can make their decision about appropriate ways to distribute their research." ${ }^{3}$ These guidelines, however, lack suggestions as to how specific kinds of computer-related activity should be evaluated within the traditional categories of professional practice, research, and service or how the traditional categories might best be revised to accommodate work with new technologies.

While technology and promotion and/or tenure are widely discussed in

Karen G. Lawson is an associate professor at Iowa State University; e-mail: klawson@iastate.edu. Nancy L.Pelzer is an associate professor at Iowa State University; e-mail: npelzer@iastate.edu. 
library literature as discrete topics, the two issues are rarely covered jointly. The use of technology on campuses and in libraries is hardly new, but there has been an obvious shift within the past decade. Technology-based projects are no longer controlled solely by an institutional "systems analyst" and are now conceived, produced and disseminated directly by faculty and staff. Concurrently, these products are included by faculty and staff in their promotional evaluation and tenure review files. In 1992, Edward Shreeves wrote that "Faculty often report that, while their interest in creating and working with electronic information sources is keen, their mentors urge them to produce traditional scholarship for publication in mainstream journals if they want to be eligible for tenure." ${ }^{4} \mathrm{~A}$ librarian, who may or may not be a faculty member, can submit a technologybased project for review for promotion or tenure evaluation. How that project is evaluated by the library administration, promotional reviewer, or tenure review committee may vary widely. The reviewing body might evaluate the project with traditional criteria or may attempt to revise evaluation criteria to accommodate computer-related work.

\section{While technology and promotion and/or tenure are widely discussed in library literature as discrete topics, the two issues are rarely covered jointly.}

In order to address this issue in more detail, the authors conducted a study to assess how technology-based projects are evaluated in the promotion and/or tenure process for librarians in Association of Research Libraries (ARL) academic libraries. This group of institutions was chosen because their emphasis on research and the possible faculty status of their librarians indicated that institutions within this group would be facing the same set of problems regarding the evaluation of technology-based projects as their counterparts on college and university campuses.

\section{Background}

How are technology-based projects evaluated for promotion and/or tenure in academe in general? Ernest Boyer suggests that the scholarly reward system can become more flexible and vital by acknowledging that scholarship can find expression in nontraditional ways, stating that "preparing quality computer software, for example, is increasingly a function of serious scholars. And even videocassette and television offer opportunity for communicating ideas to nonspecialists in creative new ways. ${ }^{\prime 5}$ Martha Gilliland writes that "the tenure system is regularly blamed for many of the perceived ills of the university" and that "faculty members' notions of development ... tend to emphasize their own fields of scholarship rather than teaching methods, the use of technology, or greater understanding of the needs and perceptions of constituencies." 6 There are an increasing number of theoretical articles that discuss the pros and cons of "new scholarship" and offer differing perspectives on how computerrelated work could be evaluated in the tenure and promotion process-revision of guidelines, creation of new guidelines and criteria, and morphing of existing guidelines and criteria. A small number of studies have attempted to gain insights about what institutions are doing to develop technology-based projects, how they are perceived in the promotion and/ or tenure process, or if and how traditional guidelines have been changed. ${ }^{7}$ In a survey sent to all deans of schools of education in the American Association of Colleges for Teacher Education, Nancy E. Seminoff and Shelley B. Wepner found that while institutions do not value technology-based projects as much as traditional scholarly works, faculty and administrators believe that technologybased projects merit equivalent value to textbooks and journal articles for tenure and promotion. Most respondents to the Seminoff and Wepner survey indicated that their institutions had not yet established criteria for evaluating technologybased projects. ${ }^{8}$ 
How are technology-based projects being evaluated in academic libraries and what rethinking, if any, is taking place regarding the place of technologybased projects in promotion and/or tenure of librarians? In 1997 Pamela S. Bradigan and Carol A. Mularski analyzed the specific criteria used by academic library directors in the tenure and promotion process, but included only journal articles and monographs as the two most common forms of publications produced by academic librarians..$^{9}$ Joan M. Leysen and William K. Black, in a survey on peer review in Carnegie Research Libraries, asked library administrators to comment on the relative importance of contributions in electronic format in the peer review process. ${ }^{10}$ There have been no studies that specifically discuss if and how technology-based projects are being assessed in promotion and/or tenure decisions in ARL academic libraries, the materials used to evaluate their merit, and the criteria assigned for the assessment of technologybased projects.

\section{Methodology}

On January 4, 1999, a survey was mailed to library administrators at 109 ARL academic libraries. An e-mail reminder was sent on January 20,1999, with a final mail reminder to non-respondents sent on February 4, 1999. The survey instrument was composed of forty-six categorical and six open-ended questions which sought to assess how technology-based projects are evaluated in the promotion and/or tenure process for librarians at these institutions. For purposes of this study, technology-based projects were defined as computer software (including CD-ROM), or the publication of articles in electronic journals, or the development of Internet-based materials (including Web pages, tutorials, or digitization), or videotapes and audiotapes. The cover letter sent with the survey included an instruction that allowed an administrator to refer the questionnaire to another person if they felt that person was more familiar with the evaluation of technology-based projects at that library. In addition to institutional information, specific inquiries were made addressing the perceived need for technology-based projects in these libraries, the actual occurrence of technology-based projects, factors that are used to determine the value of these projects, criteria that are used to determine the value of these projects in promotion and/or tenure decisions, and perceived credibility of technology-based projects in the promotion and/or tenure process. Respondents whose libraries had not experienced technology-based projects as components of librarians' promotion and/or tenure reviews during the past three years were asked to skip a portion of the survey which focused on active assessment of these projects. Results are presented as proportional analyses using the calculation of frequencies and percentages.

\section{Findings}

Seventy-seven responses from the one hundred and nine libraries contacted yielded a total of sixty-nine useable surveys, for a final return rate of $63 \%$. Not every respondent answered every question; therefore, frequency data are given, as necessary, in the text. Of the sixty-nine respondents, fifty-eight $(91 \%)$ were Carnegie I or II institutions. Thirty-six $(52 \%)$ of the responding institutions indicated that all librarians were faculty, while at four $(6 \%)$ institutions some librarians were faculty and at twenty-nine institutions ( $42 \%$ ) librarians were not faculty. In trying to assess the overall climate for scholarship requirements at ARL academic libraries, a question was posed about whether scholarly/creative activity is REQUIRED for promotion and/or tenure of librarians at their institution. Forty-two (61\%) of the libraries reported "Yes." However, in a related question which asked whether scholarly/creative activity must appear in a refereed publication, fifty-three $(77 \%)$ of the libraries said "No." Forty-four (64\%) 


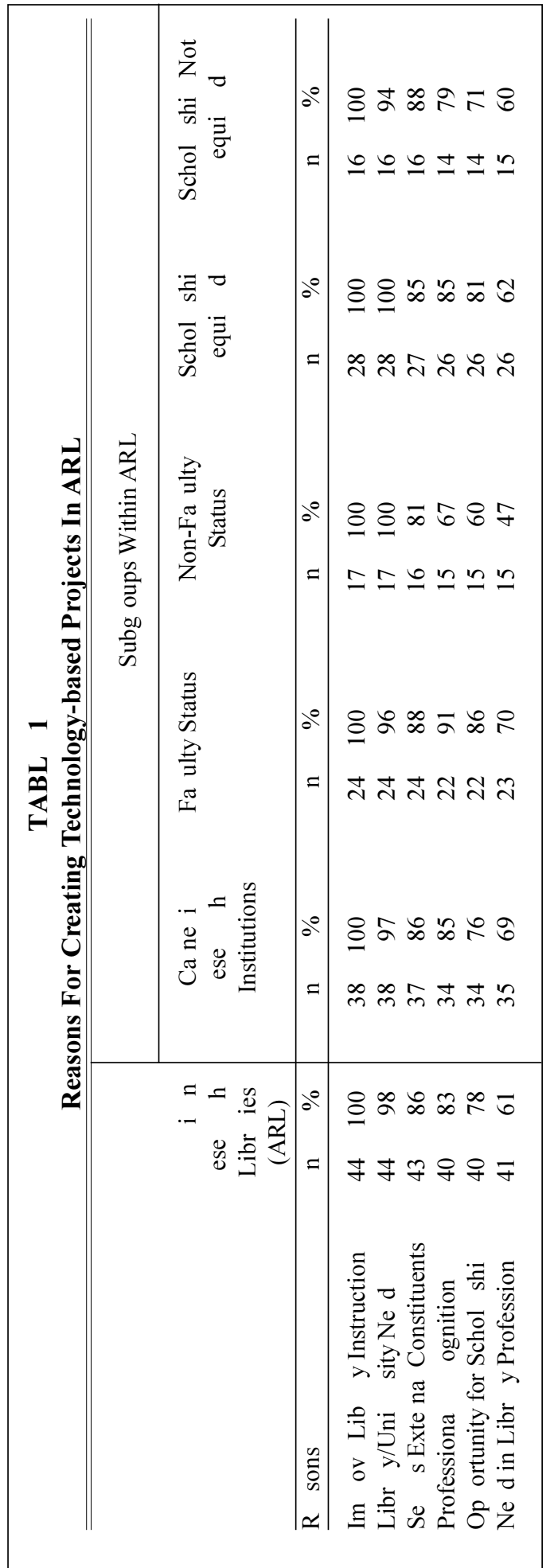

of the sixty-nine respondents said that technology-based projects had been a component of promotion and/or tenure reviews during the last three years, while twenty-five (36\%) libraries indicated that this was not the case.

Almost all of the group of forty-four libraries agreed that the reasons for creating technology-based projects were to improve library instruction or to meet a library or university need (see table 1). Eighty-six percent of these respondents believed that these projects enhanced awareness of and responsiveness to needs of constituents outside their university. Eighty-three percent of ARL academic libraries $(n=40)$ felt, also, that these projects were important for providing professional recognition to their librarians, as well as providing opportunity for research/ scholarship $(78 \%, n=40)$. A higher percentage of ARL academic libraries with faculty status than those without faculty status saw technology-based projects as an opportunity for scholarship and professional recognition. A somewhat lesser importance was ascribed to "need in the library profession," with only $61 \%$ of fortyone libraries indicating "yes" to this question. Answers to the question "Are there any other reasons why librarians at your library create technology-based projects?" included personal interest of the developer, the fact that some projects become commercial successes for their authors, an opportunity for collaboration with teaching faculty on the development of technologybased products for curricular or research use, developing distance learning programs, and participation in an important mode of scholarly communication. 


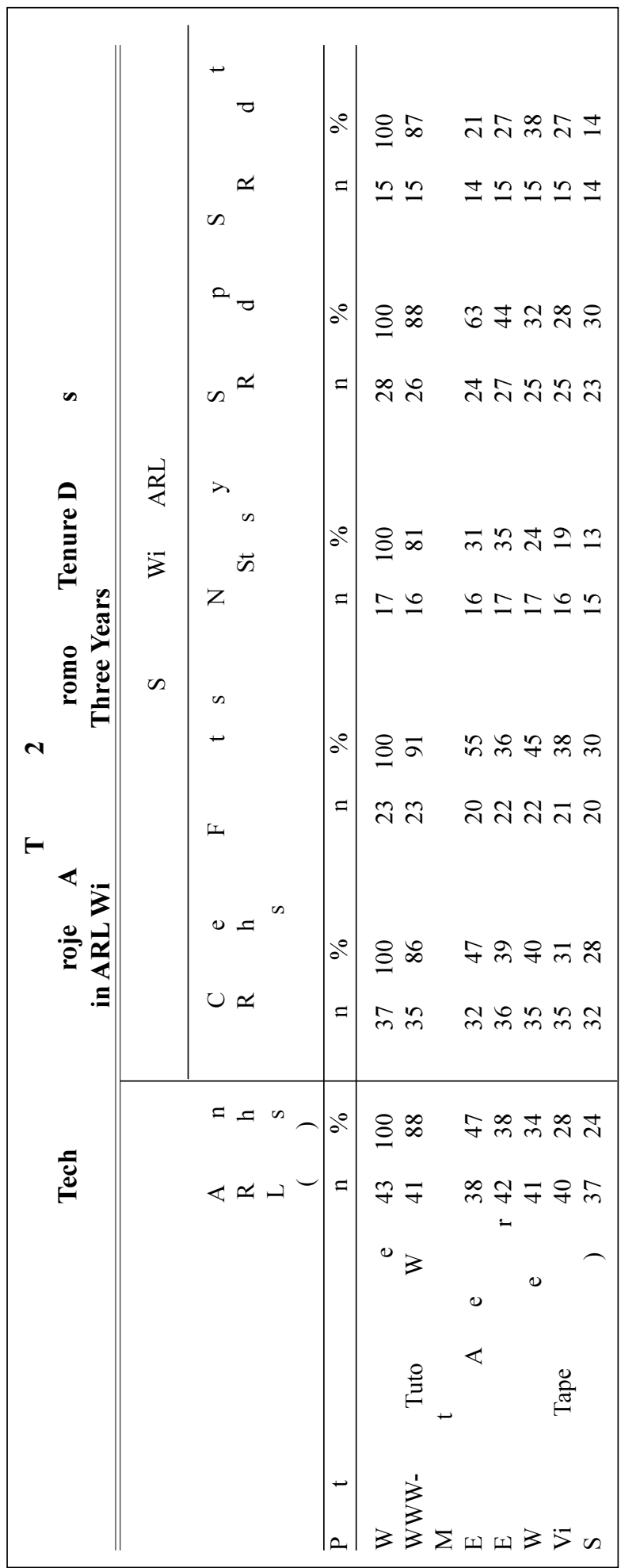

Specific Technologybased Projects That are Being Assessed

Table 2 shows the actual occurrence of various technology-based projects reported from the responding libraries.

The projects most commonly reported as being components of promotion and/or tenure decisions were World Wide Web (WWW) subject or resource pages, tutorials or other major WWW projects. Electronic journal publications were most important to those libraries which had faculty status or that required scholarship. Other projects evaluated, according to comments received in response to the question "Are there any other types of technologybased projects that have been components of promotion and/or tenure reviews in your Library?" were curricular, internal, or Internet-based. Curricular projects included a computer-based instruction lesson, CD-ROMs, collaborative projects with teaching faculty to design extensive course web sites, a video-streamed instruction module, and a grant proposal to integrate technology into the curriculum. Some internal projects evaluated were local enhancements to an online system and an electronic reserves project. Internetbased activities included the creation of Web pages for professional or consortial groups, development of a Web search en- 


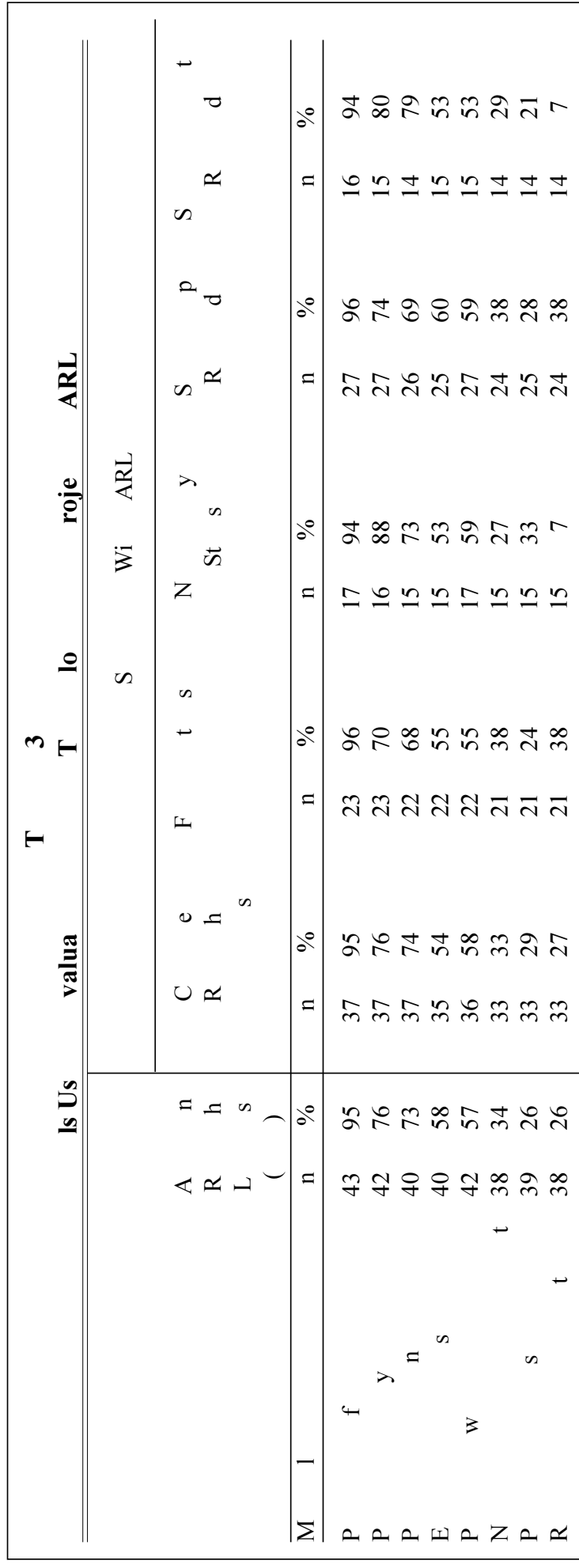

gine, some Web/gateway designs, and being an electronic journal editor-in-chief.

\section{Components Used to Evaluate Technology- based Projects}

Respondents indicated that the component most used to evaluate the merit of a technology-based project was the project itself.

Other factors used frequently (about $75 \%$ of the time) were a project summary or project description (see table 3). End-user comments and peer review were considered to be important by $58 \%$ $(n=40)$ and $57 \%(n=42)$ of the respondents, respectively. Print components, whether appearing in refereed or nonrefereed journals, and project procedures were the least important to the respondents. Another concrete component considered by one evaluator in response to the question "Are there any other materials that you might evaluate when making a decision about the merit of technologybased projects?" was an award given to a technologybased project. Other respondents considered word of mouth from the field and value to the national and international community.

\section{Criteria Used to Determine} the Merit of Technologybased Projects

The survey asked respondents to indicate which in a group of seven criteria for determining the merits of technology-based projects for promotion and/or tenure were CURRENTLY being used in their library. 


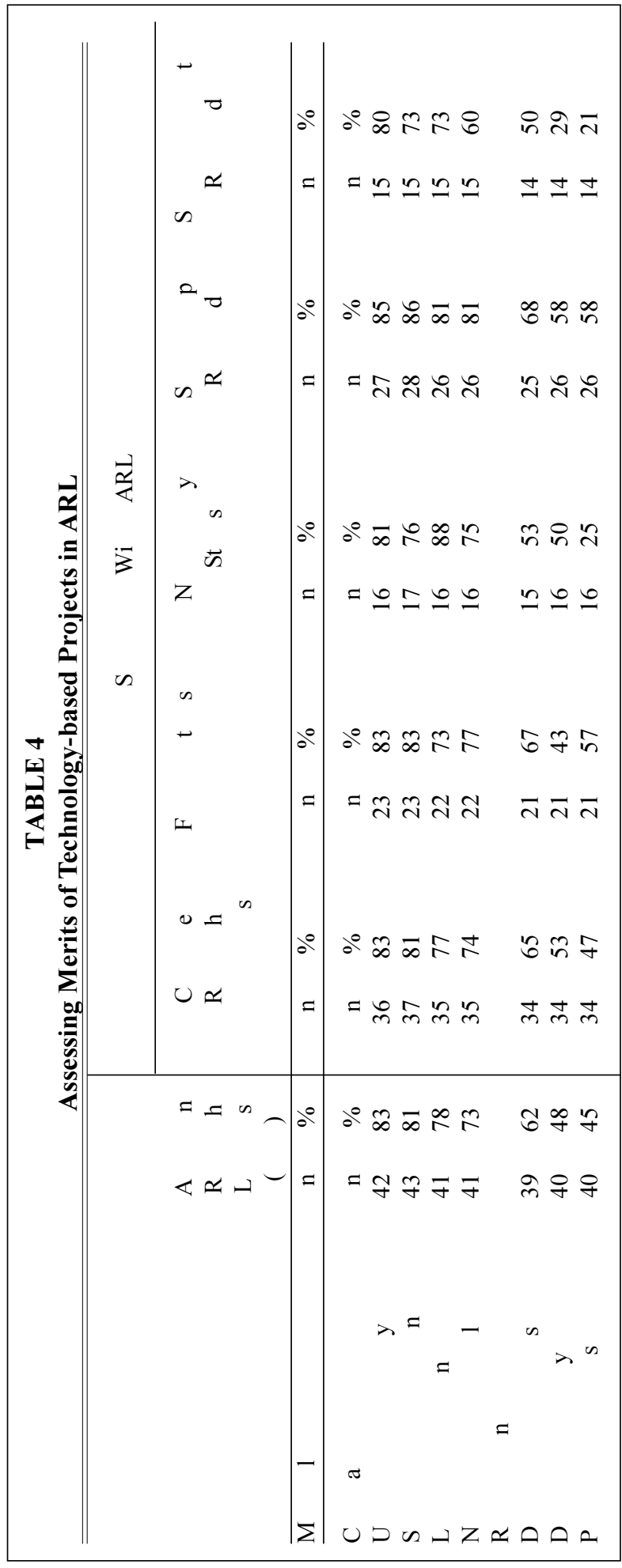

Over $80 \%$ of the reporting libraries $(n=42)$ considered the creativity or uniqueness of a technology-based project and its scholarly contribution to library science to be the primary factors in assessing the merit of a project (see table 4). Local recognition and national/international recognition of the project were factors used in assessing merit in $78 \%$ $(n=41)$ and $73 \%(n=41)$ of the respondents, respectively, while $62 \%$ also included the "logical development of ideas" $(n=39)$. Institutions with faculty status or where scholarship was required assigned a somewhat higher value to national/international recognition of projects, while those institutions with non-faculty status assigned a higher status to local recognition. Responses to the question "Are there any other criteria that are being used to determine the merit of technology-based projects for promotion and/or tenure in your library?" indicated that the other main criterion being used is whether a project is a practical utility for meeting the needs of a targeted audience. Only one institution specifically noted a willingness to consider a contribution by a librarian in any area of scholarship, not just in library science.

In a related question, the same group of seven criteria were listed and respondents were given an opportunity to indicate 
whether, in their opinion, the criteria that SHOULD be used to assess these projects were different from those currently being used. No differences were seen in respondents' answers to the two questions. Extensive comments were offered by respondents who had no technology-based projects to evaluate in the past three years, as well as those who had. Respondents with experience evaluating technology-based projects would look for usefulness and user-friendliness (to local users and users at other research libraries), promotion and enhancement of library services, and evidence of effective functioning (as an information medium and of broad-based access and use). The difficulty of the problem solved and willingness to experiment/take risks with technology-based projects, thereby contributing to the research mission of the University and the profession were other criteria offered by two Associate Deans. When asked if their library's promotion and/or tenure document included specifically written criteria for technologybased projects $88 \%$ of ARL academic libraries answered "No" ( $\mathrm{n}=59)$. However, in libraries that have faculty status or where scholarship is required, an affir- mative answer was somewhat higher $(17 \%, \mathrm{n}=36 ; 19 \%, \mathrm{n}=42)$.

\section{Regarding Credibility of Technology- based Projects}

Respondents were almost split evenly over whether they felt that technologybased projects deserved more credibility in the promotion and/or tenure process than they may currently have at their institutions: $49 \%$ answered "Yes," while $51 \%$ said "No" ( $\mathrm{n}=63)$.

Results were similar when broken down into Carnegie only institutions, and institutions with and without scholarship requirements. However, a sharp divergence was noted in those libraries with or without faculty status. Respondents from institutions with faculty status felt decidedly $(61 \%, n=33)$ that these projects did deserve more credibility, while those institutions without faculty status felt that they did not $(69 \%, n=26)$ (see figure 1$)$. Only one respondent from each of the faculty/non-faculty categories felt that technology-based projects are already treated equally with print products in promotion and/or tenure reviews.

In a final question, tenure track institutions only were asked if technology-

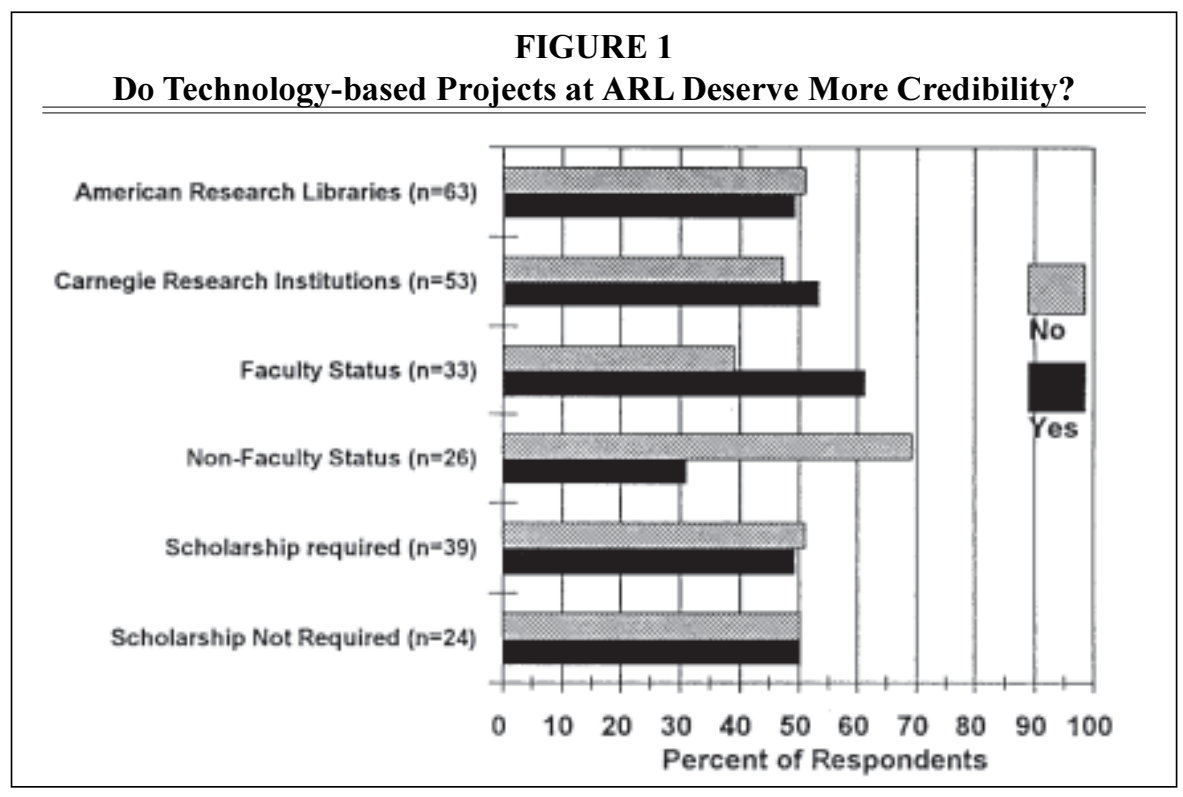


based projects alone (without accompanying traditional scholarship) would ever be sufficient evidence of scholarship for the granting of tenure. Sixty percent of the respondents felt positively that this could be the case in the future. Several added the disclaimer that "ever" was a long time and that they did not expect a change in the near future.

\section{Discussion}

Many unknowns have surrounded the issue concerning the evaluation of technology-based projects in the promotion and/or tenure process in various academic disciplines. "As candidates for jobs and promotions stock their portfolios with Internet-related accomplishments, many evaluation committees are skeptical. Behind the closed doors, committee members are asking questions that betray equal parts confusion and suspicion. Should a candidate's Internet project count? Is it teaching, scholarship, or service? Does editing an electronic journal require the same kind of rigor as editing a print journal? Who is refereeing all this stuff, anyway?"11 A respondent to our survey who answered "NO" to the question "In the last three years, have any technology-based projects that have been developed at your library been components of promotion and/or tenure reviews?" commented that "at a University library where technology plays a major role, candidates should not experience any difficulty with technologybased projects." However, evaluators and those being evaluated at institutions where these projects have been submitted for review and are increasingly included in promotion and/or tenure files are experiencing a variety of difficulties. In an effort to explore the current climate in ARL academic libraries, we asked these institutions to identify the components and criteria used to evaluate these projects. From a group of more than forty libraries that had dealt with technologybased projects in promotion and/or tenure decisions within the last three years, we have gathered a snapshot of the pro- cess at the time of the survey. Not surprisingly, we found that the majority of technology-based projects in ARL academic libraries were initiated in response to library or university need and that the majority of these projects were Internet related. We also found that, while some of the factors for dealing with these projects in promotion and/or tenure decisions were similar to those occurring in other areas of academia, others were quite different.

ARL academic libraries with faculty status took the initiative to combine "professional recognition," "opportunity for scholarship," and "need in the profession" with library/university needs as reasons for creating technology-based projects to a higher degree than did nonfaculty institutions, reflecting a higher probable need for scholarly activity. The level of creative thinking that may be involved in the conception and realization of technology-based projects may easily equal that of traditional scholarship. On a related issue, we found that refereed print components are used to make a decision about the merit of a technologybased project far more by librarians with faculty status than by those without faculty status, most probably because of more pressure to produce any type of refereed publication.

The survey showed that Internet-related technology dominates the types of technology-based projects appearing in promotion and/or tenure decisions within the past three years. No doubt libraries are responding to a market need for information that is in a convenient, easily accessible form. Many of these products are needed during a limited time frame and it may not be important that they remain part of a permanent record. However, this remains a problem to be resolved, as illustrated in the case of the archiving and retrieval of electronic journal articles. ${ }^{12}$ The fact that electronic journal articles were most important to libraries that have faculty status or that require scholarship bears out a finding from a 1997 Canadian Policy 
Conference on Scholarly Communication in the Next Millennium, that the "perception among scholars that work published electronically is less legitimate from a scholarly standpoint than work published on paper in a prestigious journal is diminishing. As scholars become connected to the Internet and involved in electronic communication they see the enormous benefits to be had." 13

Only twenty-four of the responding forty-two ARL academic libraries said that they have used peer review to evaluate the merit of technology-based project in the past three years, perhaps reflecting the lack of traditional sources for peer review of these projects. Respondents comments indicated a variety of problems with peer review: consistency of peer review procedures, not enough venues for national/international recognition, and unsureness about the peer review process in electronic journals. Many respondents from tenure-track institutions felt that peer acceptance and peer review are critical for technology-based projects if they are to be taken seriously in the promotion and/or tenure process. The American Association of the Colleges of Teacher Education has an "Innovative Use of Technology Award" program and one survey respondent would like to see "ALA/ARL sponsor a prize or two for this type of enterprise."

The survey results indicate that the evaluation criteria used currently to determine the value of technology-based projects in ARL academic libraries is for the most part in alignment with Seminoff and Wepner's study of deans of schools of education ${ }^{14}$. The deans and ARL academic libraries disagree about the relative value of two criteria. The criterion used most frequently by ARL academic libraries to assess the merit of technology- based projects was "exhibits uniqueness or creativity," while the deans of the schools of education listed "uniqueness or novelty" near the bottom (number 8 of 10) of a similar list of criteria. The education deans' third most important criteria for evaluating technol- ogy-based projects was "well-researched data collected prior to development." This is in concurrence with the MLA "Guidelines for Evaluating Computer-related Work in the Modern Languages"15 which state that "faculty members are responsible for making a case for the value of their projects, articulating the intellectual assumptions underlying their work, and documenting their time and effort ... Faculty members should be prepared to explain what theory informs their work, why their work is useful to the discipline, and the evidence of rigor and intellectual content in their work." Conversely, ARL academic libraries ranked "includes a thorough review of prior developments in the project's area of research" at the bottom of their list of criteria. All other criteria in the survey of ARL academic libraries are ranked similarly to the survey of education deans. Many respondents indicated a concern that their technology-based projects would have more credibility only when the projects of teaching faculty had more. Comments from respondents indicated that this is even a greater issue for librarians whose promotion and/or tenure files are reviewed by university committees or administrators.

\section{Conclusions}

It is clear that there is an additional burden involved for librarians who produce technology-based projects and include them in promotion and/or tenure files. Because review committees and administrators currently lack a depth of experience in evaluating these projects, the author must take the initiative in providing as much documentation of the project as possible. The concept that the "documentation of any faculty work should stress two dimensions (1) the quality of the work and (2) the significance of the work. In many instances faculty provide promotion and/or tenure committees with detailed information as to the quality of the effort; however, they do not present a case for the value of their work, describing its impact or explaining in 
what ways and for whom this work has significance"16 is doubly important if a technology-based project is up for review. Submission of documentation that shows that projects have received internal or external funding, have earned an award or other professional recognition, and reviews and citations of work either in print or in electronic journals are all useful.

Inclusion of evaluation processes for technology-based projects should be incorporated into existing library guidelines for promotion and/or tenure reviews. If an institution believes that technology-based work, like other forms of scholarship, teaching, and service, should be evaluated as an integral part of a faculty member's accomplishments, language related to teaching, scholarly/ creative activities, and professional service throughout the guidelines should also refer to computer-related work. "When an archeologist uses a ComputerAided design program to reconstruct a site, or a rhetorician moderates a fourmonth discussion online, or an historian collaborates with 120 colleagues to produce a polylog, departments and tenure/ promotion committees will need to know how to evaluate those efforts. ${ }^{17}$ Certified peer review is still an important factor for a successful review in academe, and academic librarians who must face University-wide review for promotion and/ or tenure must pay special attention to this criterion. "Whether the current form of peer review remains in place for long is of importance only inasmuch as it remains a viable measure of the life of the scholarly community. It is widely agreed that the current scholarly communication system of editorial boards, reviewers, and publishers will continue in place for at least another decade and probably much longer. Although the number and variety of scholarly publications that are exclusively electronic has grown tremendously since the 1980s, there has not yet been the kind of fundamental change that would spell the end of the current regime and the start of the new regime.
Rather, there is a gradual transformation. As more scholars establish their own communication networks and the credibility of the work being disseminated grows, the efficacy of this new means of communication will become evident and attractive." 18 It is also incumbent on administrators to make review committees understand whether or not these projects are valued at their institution.

Library evaluators seem prepared to take more risks and step outside traditional guidelines when evaluating technology-based projects when compared with their counterparts in other areas of academe. They are willing to assess the content as well as the container. Along with Janice Walker, they are finding that " we are left with three choices: first, make our electronic work somehow "fit" into existing guidelines and be able to justify it along traditional lines; second, do what we're doing now and not have it count for purposes of tenure and promotion; or, third, change the definitions of what is 'valued' to fit what we're doing." ${ }^{19}$ The respondents to the survey felt that there will be a "general change to recognize electronic scholarly activity," and that an increase in the credibility of technology-based projects "will be inevitable as [they] will become increasingly the norm as the WWW is used for services and instruction as well as access tools." "The effort to broaden the meaning of scholarship simply cannot succeed until the academy has clear standards for evaluating this wider range of scholarly work. After all, administrators and professors accord full academic value only to work they can confidently judge." 20

The results of our survey show that ARL academic librarians recognize that technology-based projects are valuable and should be seriously considered in promotion and/or tenure reviews, but 
that there has been little initiative to regularize its consideration and evaluation. A question in the survey asked tenuretrack institutions "In your opinion, will technology-based projects alone (without traditional scholarship) ever be sufficient evidence of scholarship for the granting of tenure?" The majority of respondents replied "yes," but always with a caveat. Comments offered were generally of this type: "Yes, but depends greatly on substance, quality and peer acceptance," "Yes, if there is strong and effective documentation of use and value in the academic community of the specific projects," and "Yes, I would not confuse the medium with the content. It is the content of the project that should be evaluated." It is apparent that, although the environment is dynamic and constantly evolving, there is a need for a core set of measures and assessment techniques that evaluate technology-based projects. Academic librarians can look at the evaluation criteria and guidelines used by other academic institutions and other disciplines in the consideration of technology-based projects and compare them with their own organization's evaluation processes. Academic librarians can play an important role in addressing the serious questions about technology-based projects that are before us.

\section{Notes}

1. Thomas J. DeLoughry, "Professors Report Progress in Gaining Recognition for Their Use of Technology," Chronicle of Higher Education 39, no. 26 (March 3, 1993): A19, A21.

2. Lisa Guernsey, "Scholars Who Work With Technology Fear They Suffer in Tenure Reviews," Chronicle of Higher Education 43, no. 39 (June 6, 1997): A21-22.

3. Modern Language Association. MLA Committee on Computers and Emerging Technologies in Teaching and Research, "Guidelines for Evaluating Computer-related Work in the Modern Languages," ADE Bulletin 114 (1996): 44-46.

4. Edward Shreeves, "Between the Visionaries and the Luddites: Collection Development and Electronic Resources in the Humanities," Library Trends 40, no. 4 (spring 1992): 579-95.

5. Ernest L. Boyer, Scholarship Reconsidered: Priorities of the Professoriate (Princeton, N.J.:Carnegie Foundation for the Advancement of Teaching, 1990), 36.

6. Martha W. Gilliland, "Organizational Change and Tenure: We Can Learn From the Corporate Experience," Change 29, no. 3 (May/June 1997): 30-33.

7. For example, see: Devorah A. Lieberman and John Rueter, "The Electronically Augmented Teaching Portfolio," in The Teaching Portfolio : a practical guide to improved performance and promotion/tenure decisions $2^{\text {nd }}$ ed., Peter Seldin (Bolton, MA.:Anker Publishing Company, 1997), 46-57. Blaise Cronin and Kara Overfelt, "E-Journals and Tenure," Journal of the American Society for Information Science 46, no. 9 (October 1995): 700-2. Nancy E. Seminoff and Shelley B. Wepner, "What Should We Know About Technology-Based Projects for Tenure and Promotion?," Journal of Research on Computing in Education 30, no. 1 (fall 1997): 67-82. "Tenure and Technology: New Values, New Guidelines" in Kairos: A Journal for Teachers of Writing in Webbed Environments 2, no. 1 (spring 1997) ( http:/ / english.ttu.edu/kairos) includes: Cindy Nahrwold "'Just' Professing; A Call for the Valuation of Electronic Scholarship, Seth R. Katz "One Department's Guidelines for Evaluating Computer-related Work, Janice R. Walker "Fanning the Flames: Tenure and Promotion and Other Role-Playing Games," Janet Cross and Kristian Fuglevik "Jesters Get Serious."

8. Nancy E. Seminoff and Shelley B. Wepner, "Are Technology-Based Projects Valued as Scholarship for Tenure and Promotion?," Journal of Computing in Teacher Education 11, no. 3 (1995): 5-10.

9. Pamela S. Bradigan and Carol A. Mularski, "Evaluation of Academic Librarians' Publications for Tenure and Initial Promotion," Journal of Academic Librarianship 22, no. 5 (September 1996): 360-65.

10. Joan M. Leysen and William K. Black, "Peer Review in Carnegie Research Libraries," College \& Research Libraries 59, no. 6 (November 1998): 512-522.

11. Guernsey, "Scholars Who Work With Technology," A21.

12. Charlotte E. Ford and Stephen P. Harter, "The Downside of Scholarly Electronic Publishing: Problems in Accessing Electronic Journals through Online Directories and Catalogs," College \& Research Libraries 59, no. 4 (July 1998): 335-346. 
13. Kenneth Field, "Faculty Perspective on Scholarly Communication," Canadian Journal of Communication 22, no. 3/4 (1997): 161-178.

14. Seminoff and Wepner, "What Should We Know," 70.

15. Modern Language Association, "Guidelines for Evaluating," 45.

16. Robert M. Diamond, Serving on Promotion and Tenure Committees: A Faculty Guide. (Bolton, MA.:Anker Publishing Co. Inc., 1994), 18.

17. Paul LeBlanc "Pulling Out the Rug: Technology, Scholarship, and the Humanities" in The Politics and Processes of Scholarship edited by Joseph M. Moxley and Lagretta T. Lenker (Westport, Connecticut; London: Greenwood Press, 1995), 122-123.

18. Field, "Faculty Perspective," 165.

19. Walker, "Fanning the Flames," (http://english.ttu.edu/kairos/2.1/index_f.html)

20. Charles E. Glassick, Mary Taylor Huber, and Gene I. Maeroff, Scholarship Assessed: Evaluation of the Professoriate (San Francisco: Jossey-Bass Publishers, 1997), 5. 